\title{
Alterations in choroid plexus gene expression in Alzheimer's disease provide inferences for CSF composition and dynamics
}

\author{
Miles C Miller ${ }^{1 *}$, Edward G Stopa', Elena V Nikonova², Keith Q Tanis², Alexei A Podtelezhnikov², Eva M Finney², \\ David J Stone', Luiz M Camargo², Lisan Parker², Ajay Verma², Andrew Baird ${ }^{3,4}$, John E Donahue', \\ Ana Maria Gonzalez ${ }^{4}$, Brian Eliceiri ${ }^{3}$, Gerald D Silverberg ${ }^{1}$, Petra M Klinge', Conrad E Johanson ${ }^{1}$ \\ From 54th Annual Meeting of the Society for Research into Hydrocephalus and Spina Bifida \\ Vancouver, Canada. 7-10 July 2010
}

\section{Background}

Alterations in CSF composition are associated with normal aging and the pathophysiology of Alzheimer's disease and NPH. These changes may contribute to modified choroid plexus function in these states. Disease-related changes in choroid plexus gene expression were investigated using human Affymetrix 48K gene arrays.

\section{Materials and methods}

Lateral ventricle choroid plexuses were excised at autopsy from healthy aged controls (mean age/mean PMI: 58 years/22 hours) and patients with advanced (Braak \& Braak stage V-VI) Alzheimer's disease (79/18). Diseased control patients with frontotemporal dementia (72/NA) and Huntington's disease (71/19) were also sampled. All tissue specimens were snap frozen in liquid nitrogen and stored at $-80^{\circ} \mathrm{C}$ until use. RNA was extracted from choroid plexuses with Trizol followed by NuGEN Ovation amplification, and cDNA was hybridized to custom chips at Rosetta/Merck. RMA normalization was performed, and data were analyzed using one way ANOVA to identify the gene sets of greatest significance. These sets were then analyzed further for biological enrichment using individual (Ingenuity) and combined (Target and Gene Information System) pathway tools.

\footnotetext{
* Correspondence: Miller.Miles.C@gmail.com

'Departments of Neurosurgery and Pathology (Neuropathology Division), Rhode Island Hospital, The Warren Alpert Medical School, Brown University, Providence, RI, USA

Full list of author information is available at the end of the article
}

\section{Results}

Differences on the level of gene expression were seen in the choroid plexuses of Braak \& Braak V-VI AD patients when compared to both the normal and diseased (FTD, HD) control groups. Four experimental groups could significantly be separated out based on the analyses of 648 sequences $(\mathrm{p}<0.001, \mathrm{FDR} \sim 8 \%)$, with close to fifty percent of those sequences being upregulated in neurodegenerative disease states. There was a significant increase in immune response noted in advanced $A D$ patients, while amyloid processing and oxidative phosphorylation were both down-regulated in these cases. In addition, cellular adhesion function and extracellular matrix re-modeling were highly enriched in the advanced $\mathrm{AD}$ patients when compared to both the healthy and diseased controls. Other important observations that were made in analyzing these data include: decreases in PPARa/RXRa nuclear receptor/retinoic acid, a-adrenergic, glucocorticoid and melatonin signaling, as well as $\mathrm{N}$-glycan, glutathione (antioxidant) and ubiquinone metabolism in $\mathrm{AD}$ choroid plexuses.

\section{Conclusions}

These gene expression profiles may serve as valuable resources to investigators working in the fields of aging CSF dynamics and hydrocephalus. It is readily available and can be shared with interested investigators to address specific questions pertaining to their area of investigation.

\footnotetext{
Author details

'Departments of Neurosurgery and Pathology (Neuropathology Division), Rhode Island Hospital, The Warren Alpert Medical School, Brown University,
} 
Providence, RI, USA. ${ }^{2}$ Molecular Profiling \& Research Informatics, Merck Sharp \& Dohme, West Point, PA, USA. ${ }^{3}$ Department of Surgery, University of California San Diego Medical Center, Hillcrest, 212 Dickinson Street, San Diego, CA, USA. ${ }^{4}$ School of Clinical and Experimental Medicine, College of Medical and Dental Sciences, University of Birmingham, Edgbaston, UK.

Published: 15 December 2010

doi:10.1186/1743-8454-7-S1-S48

Cite this article as: Miller et al: Alterations in choroid plexus gene expression in Alzheimer's disease provide inferences for CSF

composition and dynamics. Cerebrospinal Fluid Research 2010 7(Suppl 1): S48

Submit your next manuscript to BioMed Central and take full advantage of:

- Convenient online submission

- Thorough peer review

- No space constraints or color figure charges

- Immediate publication on acceptance

- Inclusion in PubMed, CAS, Scopus and Google Scholar

- Research which is freely available for redistribution 